\title{
Evaluation of the significance of the effect of the active cross-sectional area of the inlet air channel on the specific enthalpy of the exhaust gas of a diesel engine using statistics $\mathbf{F}$ of the Fisher-Snedecor distribution
}

\begin{abstract}
This paper presents the application of Fisher-Snedecor distribution F statistics to assess the significance of the influence of changes in the active cross-sectional area of the inlet air channel $\left(A_{d o l}\right)$ flow in a diesel engine on the observed diagnostic parameter determined on the basis of measurements of the quick changing exhaust gas temperature in the outlet channel, which is the specific enthalpy of the exhaust gas stream within one engine operating cycle $\left(h_{\text {spal }}\right)$. A plan of experimental tests carried out on the laboratory stand of a single-cylinder Farymann Diesel type D10 laboratory engine was presented and the method of determination of $F$ statistics values for the obtained measurement results was characterized. Representative results of calculations were presented and the strength of $A_{\text {dol }}$ input parameter influence on the determined diagnostic parameter hspal simplified physical model of the working process of a compression ignition engine as the object of diagnosis was evaluated. It is planned to further develop the experimental research program to determine the significance of the influence of changes in the values of selected parameters of the engine structure on other diagnostic measures determined from the exhaust gas temperature signal, i.e. the mean peak-to-peak value as well as the rate (intensity) of increase and decrease in its value for individual engine cycles.
\end{abstract}

Key words: diesel engine, exhaust gas temperature, Fisher-Snedecor decomposition F statistic, diagnosis

\section{Introduction}

Diagnostics of the working spaces of a diesel engine, together with inlet air and exhaust gas ducts, is an important operational issue $[3,17]$. The key stage of diagnosis is the process of parametric inference, allowing to determine the relationships between the state of the structural structure of a diesel engine and the observed parameters of its operation (control parameters) [2, 7]. One of the output parameters of the engine enabling such an operation is the fast-changing temperature of exhaust gases recorded in the outlet channel $[8,10]$. However, in order to apply a diagnosis methodology based on this parameter, it is necessary to develop an appropriate measurement technology, taking into account the test conditions and measurement uncertainty. In the case of dynamic exhaust gas temperature measurements, the most appropriate seems to be the use of thermocouples with the lowest inertia [4]. Its time course, obtained during tests on a real object, which is a diesel engine, is burdened with numerous interferences resulting from environmental influences and the measurement network. Therefore, it should first be subjected to an appropriate mathematical treatment allowing to reproduce the course closest to the real one [11]. However, it will be of no use to the diagnostician without a properly developed test program and properly selected tools for statistical and substantive analysis of the obtained measurement data, including diagnostic inference $[5,9]$.

During the diagnostic test of the engine, in the steady state of operation, diagnostic parameters D are obtained from among its output parameters $\mathrm{Y}$, which react more strongly to changes in the value of the structural parameters $\mathrm{S}$ than to changes in the value of the input parameters $\mathrm{X}$, forcing the work process. The basic condition for selecting the appropriate diagnostic parameters is a much higher sensitivity of the output parameter in relation to the $\mathrm{W}_{\mathrm{S}}^{\mathrm{Y}}$ structure parameter than its sensitivity to the $\mathrm{W}_{\mathrm{X}}^{\mathrm{Y}}$ input parameter [3]:

$$
\begin{gathered}
W_{S}^{Y}=\frac{\partial Y}{\partial S}=\frac{\frac{\Delta Y}{Y_{0}}}{\frac{\Delta S}{S_{0}}}=\frac{\frac{Y_{\text {pom }}-Y_{0}}{Y_{0}}}{\frac{S_{\text {pom }}-S_{0}}{S_{0}}} \gg W_{X}^{Y}= \\
=\frac{\partial Y}{\partial X}=\frac{\frac{\Delta Y}{Y_{0}}}{\frac{\Delta X}{X_{0}}}=\frac{\frac{Y_{p o m}-Y_{0}}{Y_{0}}}{\frac{X_{p o m}-X_{0}}{X_{0}}}
\end{gathered}
$$

Comparison of the sensitivity of many control parameters, given in different units of measurement, makes it necessary to adopt relative values of input, output and structure parameters for this purpose.

There are many methods of assessing the significance of the impact of the parameters that force the analyzed physical process on its course. These include the concept known from classical mathematical analysis, which is the distance between functions (metrics), information entropy derived from information theory (formulated for the first time in 1945 by Shannon), as well as non-parametric and parametric statistical tests $[3,5,6,15]$.

In the case of assessing the significance of the impact of one engine input parameter or one structural parameter on one output parameter, i.e. quick changing exhaust gas temperature, the most appropriate seems to be the application of a randomized static test program complete and the adoption of Fisher-Snedecor distribution F statistics for analysis $[5,16]$. In order to determine the significance of the effect of engine load on the defined, observed in the diagnostic process, output parameters, it was necessary to carry out the research according to a simplified physical model of the working process of a diesel engine presented in Fig. 1. 


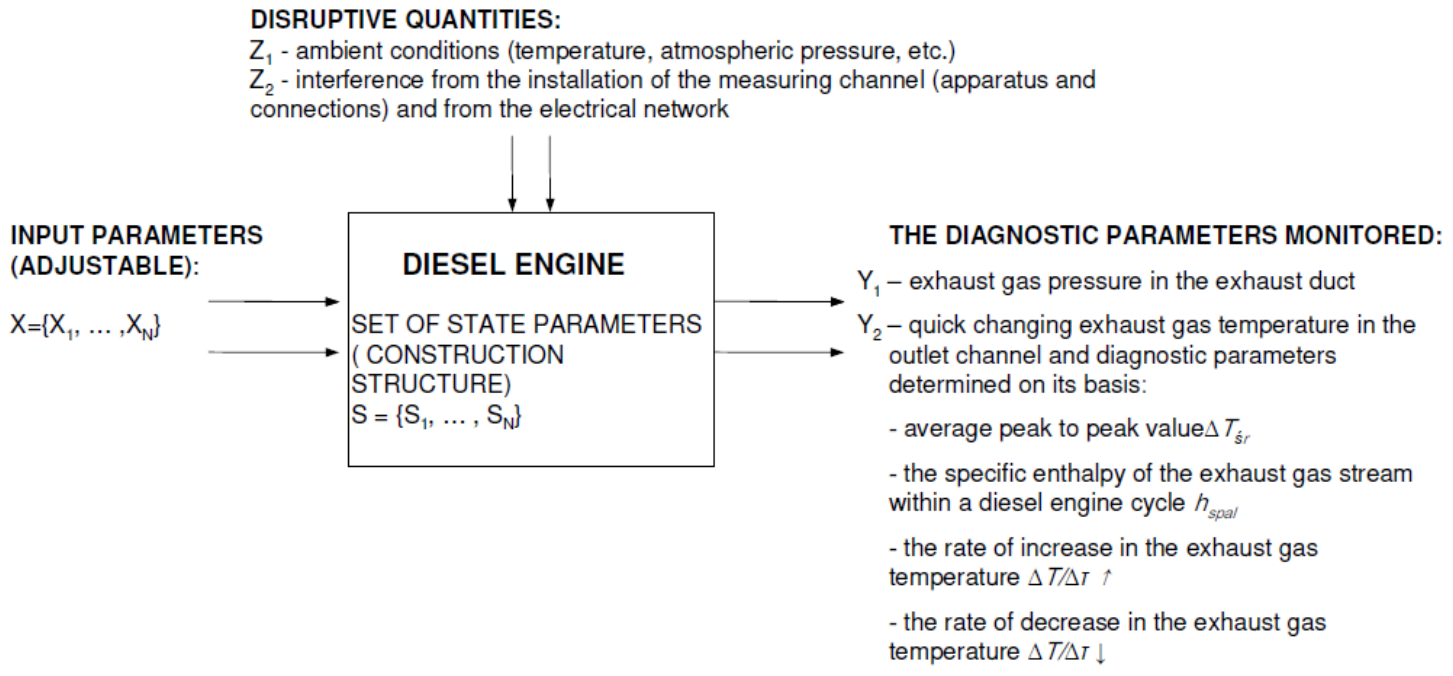

Fig. 1. Simplified physical model of the diesel engine operating process for diagnostic purposes

\section{Use of Fisher-Snedecor decomposition statistics $\mathbf{F}$ to} assess the significance of the impact

Due to the nature of the research conducted, a complete randomized static program was used [5], which allows to assess the significance of the impact of one input factor of the physical model of the process under study on one output factor. The zero hypothesis, formulated in advance and verified in statistical studies, assumes no influence of the input factor on the resultant factor. An input factor is considered significant when the computational value of the adopted statistics is equal to or greater than the critical value given in the tables for the adopted value of the significance level and number of degrees of freedom. It was considered that the Fisher-Snedecor decomposition F statistic of the Fisher-Snedecor decomposition is best suited for diagnostic testing of a diesel engine because the conditions for the use of unilateral parametric tests are met. It was assumed in advance that the results of measurements of all control parameters can be modelled as random variables with normal distribution, a specific expected value and variance, being a measure of the scatter around the mean value. It was also assumed that the variances of random variables are equal or close to the value, and the applied parametric tests concerning the variance are characterized by one-sided critical area. The possibility of making a first type error (equal to $\alpha$ ) associated with an arbitrarily accepted level of materiality, i.e. the probability of rejecting the zero hypothesis when it is true, was also considered. However, the possibility of making a second type of error, i.e. assuming the zero hypothesis when it is false, of $\beta=1-\alpha$ [5].

Table 1 presents an exemplary matrix of an experimental test programme, in this case a randomised static plan, allowing the assessment of the significance of the influence of the input factor considered in the diagnostic tests of a diesel engine - the active cross-sectional area of the $A_{\text {dol }}$ inlet air channel on the diagnostic parameter (output factor), which is the unit enthalpy of the exhaust gas stream within one operating cycle $-\mathrm{h}_{\text {spal }}$.
Table 1. Matrix of the experimental research programme - complete randomized static plan

\begin{tabular}{|l|c|c|c|}
\hline \multirow{2}{*}{ Level of input factor } & \multicolumn{3}{|c|}{ Number of experience } \\
\cline { 2 - 4 } & 1 & $\ldots$ & 6 \\
\hline $\mathrm{A}_{\text {dol } 1}$ & $\mathrm{~h}_{\text {spal11 }}$ & $\ldots$ & $\mathrm{h}_{\text {spal61 }}$ \\
\hline $\mathrm{A}_{\text {dol } 2}$ & $\vdots$ & $\vdots$ & $\vdots$ \\
\hline $\mathrm{A}_{\text {dol 3 }}$ & $\mathrm{h}_{\text {spal13 }}$ & $\ldots$ & $\mathrm{h}_{\text {spal63 }}$ \\
\hline
\end{tabular}

The test (calculation) value of the Fisher-Snedecor ${ }^{1}$ distribution $\mathrm{F}$ statistics is determined from the following relationship:

$$
F=\frac{\sum_{i=1}^{p} n_{i} \cdot\left(\overline{h_{l}}-\bar{h}\right)^{2} \cdot(n-p)}{\left[\sum_{i=1}^{p} \sum_{j=1}^{q}\left(\overline{h_{l \jmath}}-\bar{h}\right)^{2}-\sum_{i=1}^{p} n_{i} \cdot\left(\overline{h_{l}}-\bar{h}\right)^{2}\right] \cdot(p-1)}
$$

where: $n_{i}$ - number of measurements of specific enthalpy at a given level, $n-$ total number of measurements, $\bar{h}_{1}-$ average specific enthalpy from the measurements in the i-line, $\bar{h}$ - average specific enthalpy from all measurements, $h_{i j}$ the value of the $\mathrm{j}$ specific enthalpy at the i-level, $\mathrm{p}$ - number of levels of variation of the input medium (active crosssectional area of the inlet air).

The calculated test value of the $\mathrm{F}_{\text {obl }}$ statistics is then compared with its critical value $F_{k r}$ determined from the relevant statistical table, for the assumed level of materiality $\alpha$ and for the designated numbers of degrees of freedom calculated for the numerator and denominator of the statistic value $F: f_{1}$ and $f_{2}$. If the determined $F_{\text {obl }}$ value is greater than or equal to the $F_{k r}$ critical value, the effect of the test factor should be considered significant. Otherwise, within the tested range of volatility and at the assumed level of materiality, the tested input factor is considered not to be significantly influenced by the output factor.

\section{Influence of diesel engine structure parameters on the specific enthalpy of exhaust gases}

In order to obtain the value of F statistics, and thus the answer to the key question concerning the significance of the influence of the tested input factors of the simplified

\footnotetext{
${ }^{1}$ In the following, it is also referred to as "F statistics" for short.
} 
physical model of the diesel engine working process on the defined diagnostic measures, it was necessary to follow the developed scheme of research implementation - Fig. 2.

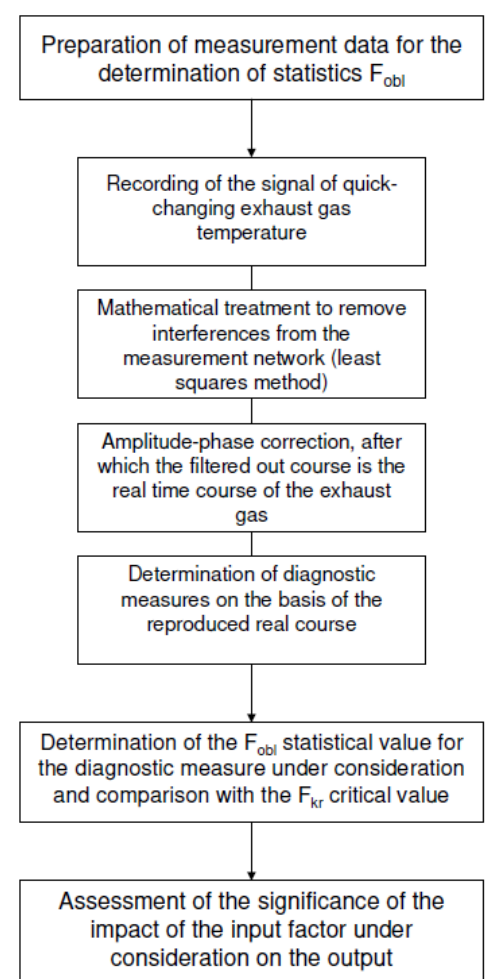

Fig. 2. Stages of preparation of measurement data for determination of Fisher-Snedecor statistic F decomposition for diagnostic purposes

The main objective of the empirical research is to determine the diagnostic information of the observed control parameter, which is a quick changing temperature of the

a)

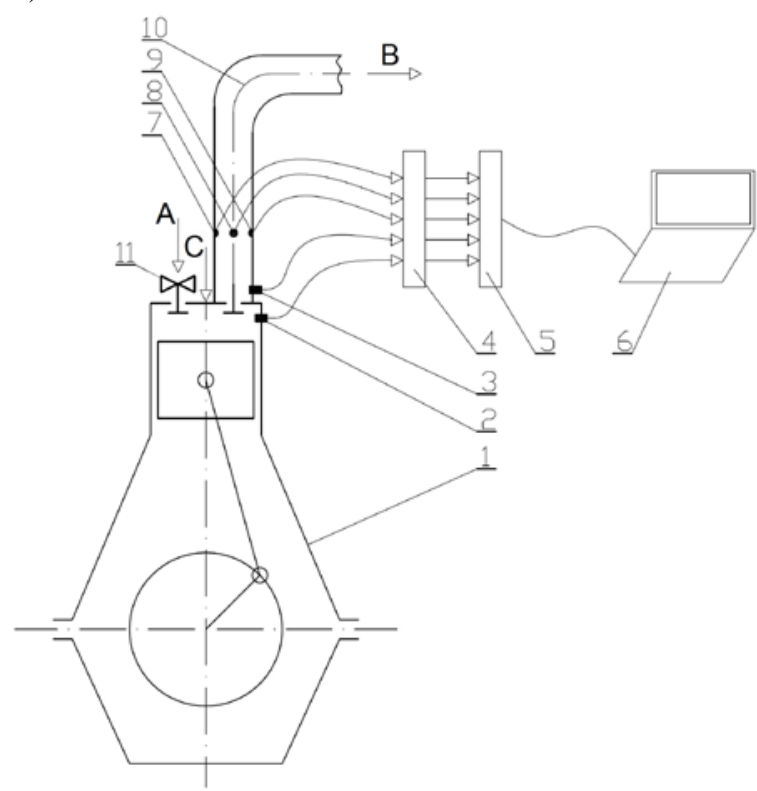

exhaust gas of a diesel engine loaded with a DC generator. Therefore, its sensitivity to changes in the parameters of its construction structure should be determined. In the discussed next stage of research [13], the significance of the influence of the active cross-sectional area of the $A_{d o l}$ inlet air channel on one of the diagnostic measures obtained from the reproduced, real course of the quick changing exhaust gas temperature - the specific enthalpy of the exhaust gas stream within the range of one engine operation cycle was evaluated. The experiment was carried out according to the plan presented in tabular form - Table 2.

Table 2. Engine test plan to determine the significance of the effect of its active cross-sectional area of the Adol intake air channel on the specific enthalpy of the exhaust gas stream within one $h_{\text {spal }}$ working cycle

\begin{tabular}{|l|c|c|c|c|c|c|}
\hline \multirow{2}{*}{$\begin{array}{c}\text { Para- } \\
\text { meter }\end{array}$} & \multicolumn{6}{|c|}{$\begin{array}{r}\text { Points of regulatory characteristics according } \\
\text { to the implemented plan }\end{array}$} \\
\cline { 2 - 7 } & $\begin{array}{c}\mathrm{A}_{\mathrm{dol}} \\
{\left[\mathrm{m}^{2}\right]}\end{array}$ & $\begin{array}{c}\mathrm{P}_{\text {obc }} \\
{[\mathrm{W}]}\end{array}$ & $\begin{array}{c}\mathrm{I} \\
{[\mathrm{A}]}\end{array}$ & $\begin{array}{c}\mathrm{U} \\
{[\mathrm{V}]}\end{array}$ & $\begin{array}{c}\mathrm{n} \\
{\left[\mathrm{min}^{-1}\right]}\end{array}$ & $\begin{array}{c}\text { Number } \\
\text { of repe- } \\
\text { titions }\end{array}$ \\
\hline $\mathrm{A}_{\text {dol } 1}$ & $804 \times 10^{-6}$ & 432 & 5.1 & 72 & 1444 & 6 \\
\hline $\mathrm{A}_{\text {dol } 2}$ & $603 \times 10^{-6}$ & 432 & 5.1 & 72 & 1444 & 6 \\
\hline $\mathrm{A}_{\text {dol } 3}$ & $401 \times 10^{-6}$ & 432 & 5.1 & 72 & 1444 & 6 \\
\hline $\mathrm{A}_{\text {dol } 1}$ & $804 \times 10^{-6}$ & 768 & 6.8 & 96 & 1444 & 6 \\
\hline $\mathrm{A}_{\text {dol } 2}$ & $603 \times 10^{-6}$ & 768 & 6.8 & 96 & 1444 & 6 \\
\hline $\mathrm{A}_{\text {dol } 3}$ & $401 \times 10^{-6}$ & 768 & 6.8 & 96 & 1444 & 6 \\
\hline $\mathrm{A}_{\text {dol } 1}$ & $804 \times 10^{-6}$ & 1200 & 8.5 & 120 & 1444 & 6 \\
\hline $\mathrm{A}_{\text {dol } 2}$ & $603 \times 10^{-6}$ & 1200 & 8.5 & 120 & 1444 & 6 \\
\hline $\mathrm{A}_{\text {dol } 3}$ & $401 \times 10^{-6}$ & 1200 & 8.5 & 120 & 1444 & 6 \\
\hline
\end{tabular}

Both the motor load and the current and voltage at the generator terminals changed by $25 \%$ compared to the nominal value for the regulatory characteristics according to the implemented test program. For construction and regulatory

b)

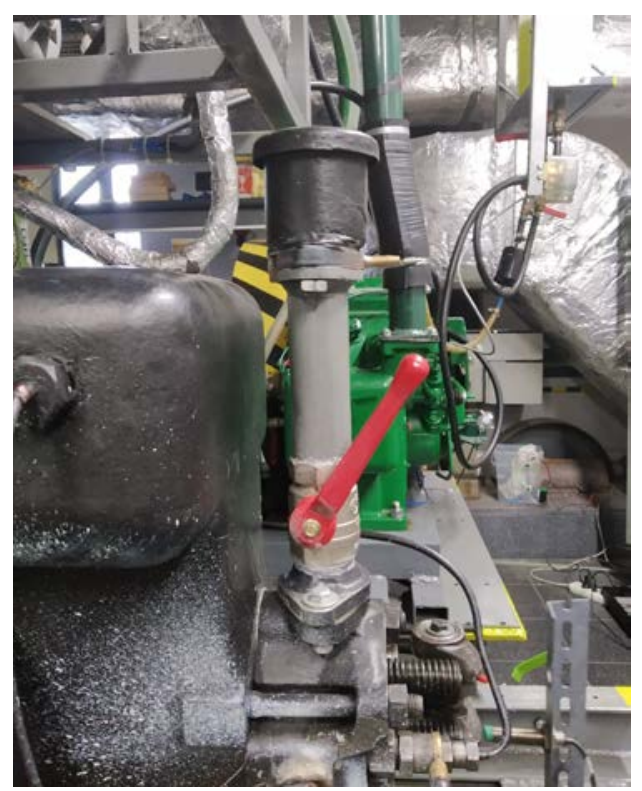

Fig. 3. a) Diagram of the laboratory stand with marked places of sensor installation: 1 - Farymann Diesel engine type D10, 2 - top deadlock and speed sensor, 3 - outlet valve opening sensor, 4 - A/C converter, 5 - recorder, 6 - analysis program, 7 - water-cooled thermocouple, 8 - pressure sensor, 9 bimetal thermometer, 10 - flue gas outlet channel, 11 - ball valve regulating the air supply, A - inlet air, B - exhaust gases, $\mathrm{C}$ - supply fuel; b) view of the engine inlet air ball valve 
reasons, it was not possible to obtain $25 \%$ changes from the nominal value for all 3 operating parameters simultaneously (P, I, U). Small deviations from these values in the case of engine power do not significantly affect the diagnostic parameters analysed, because the engine operated in a small load range. Also the value of the active cross-sectional area of the inlet air channel $A_{\text {dol }}$ changed its value by $25 \%$ in relation to the reference state, understood as full opening of the air control valve, which simulated the loss of the filter baffle. The active cross-sectional area of the inlet air duct flow was changed in 3 ranges (100\% - $804 \mathrm{~mm}^{2}, 75 \%-$ $603 \mathrm{~mm}^{2}, 50 \%-401 \mathrm{~mm}^{2}$ ).

The operating states of a steady state diesel engine distinguish three characteristics of its operation (Fig. 4). In the conducted tests, the speed characteristics are based on the speed characteristic - typical for the operation of the main engine driving a fixed pitch propeller when it does not have a speed controller. The engine is loaded according to the socalled external speed characteristic. Then, a constant dose of fuel is maintained for the engine operation cycle, while the range of rotational speed changes results from the selfregulation of the engine rotational speed during the ship's sailing on a wave [1].

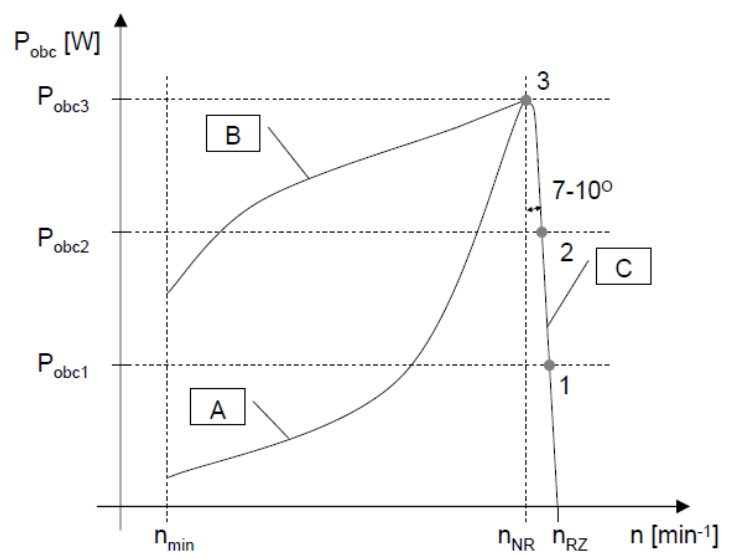

Fig. 4: Characteristics of the ship engine load variation as a function of the crankshaft rotational speed: A - screw speed characteristics (variable fuel feed per engine operating cycle); $\mathrm{B}$ - external speed characteristics (fixed fuel feed per engine operating cycle), $\mathrm{C}$ - regulator characteristics (variable fuel feed per engine operating cycle), $\mathrm{n}_{\mathrm{NR}}-$ speed regulator setting, $\mathrm{n}_{\mathrm{RZ}}$ - actual speed

Experimental research was carried out on the laboratory stand of a single-cylinder Farymann Diesel type D10 engine, which drives a PKM0a44a/143 type foreign-excited DC generator through a belt transmission. Nominal values of the basic parameters of the drive motor are: $\mathrm{P}_{\text {nom }}=5.9$ $\mathrm{kW}, \mathrm{M}_{\text {nom }}=38 \mathrm{~N} \cdot \mathrm{m}$ and $\mathrm{n}_{\text {nom }}=1500 \mathrm{~min}^{-1}$. Due to the significant wear and tear of the test engine and limited capabilities of the load control system and fuel dose control system, the measurements of the observed parameters were carried out for 3 operation points according to the regulatory characteristics (Table 2). A multifunctional measuring and recording module type DT-9805 from Data Translation was used to record the measurements of fast-changing exhaust gas temperatures and pressures, as well as the signal of the top dead position of the piston. Matlab and Microsoft Excel software were used to record and mathematically process the recorded values of fast-changing exhaust gas temperature.

The engine crankshaft speed was maintained at a constant level during the research $\left(1444 \mathrm{~min}^{-1}\right)$. MGO marine fuel was used to power it. The sampling frequency was $7017.54 \mathrm{~Hz}$. A K-type thermocouple with a welded joint to a jacket with an external diameter of $0.5 \mathrm{~mm}$, made of Inconell, additionally cooled with a water jacket, was used to measure the flue gas temperature [14]. The time constant of the applied thermocouple was determined according to the algorithm presented in the publication [11] and is $6.49 \cdot 10^{-3} \mathrm{~s}$. The signal to open the exhaust valve was recorded by using a gap type optoisolator with LM393 comparator.

The value of the average specific heat of the exhaust gases was determined on the basis of the knowledge of the basic chemical composition burned during the test of the MGO marine fuel $(\mathrm{C}=0.8626, \mathrm{H}=0.111)$, as well as through the measurement of the $\lambda$ excess air ratio during the engine test and table data such as the specific heat of air and components of stoichiometric exhaust gas [13]. All specific heat values depend on the average value of the exhaust gas temperature recorded during the engine diagnostic test.

Tables 3a, 3b and 3c show the values of the defined output medium, which is the specific enthalpy of the exhaust gas stream within one engine cycle, for three states of steady state engine load, forced by the set values of the voltage and current of the generator. Points $\mathrm{P}_{1}, \mathrm{P}_{2}$ and $\mathrm{P}_{3}$ defined by these parameters result from the assumed regulatory characteristics of engine operation - Fig. 4. The structure parameter, being an input factor with 3 different levels of variability in each of points $\mathrm{P}_{1}, \mathrm{P}_{2}$ and $\mathrm{P}_{3}$, was the active cross-sectional area of the inlet air flow channel $A_{\text {dol }}$.

In order to determine the value of the $F_{\text {obl }}$ statistics, the following zero hypothesis has been put forward $\mathrm{H}_{0}$ :

\section{$H_{0}$ : the active cross-sectional area of the $A_{d o l}$ inlet air channel does not affect the value of the specific enthalpy of the exhaust stream averaged over one engine cycle $\left(\mathrm{S}_{\mathrm{II}}^{2}=\mathrm{S}_{\mathrm{I}}^{2}\right)$}

On the basis of the figures in Tables 3a, 3b and 3c and the assumed level of significance $\alpha=0.05$ and the assumption of a right-handed critical area, the following were determined: the unit value of the enthalpy of the exhaust stream within one engine cycle, for each measuring point $\left(A_{i}\right)$, the number of degrees of freedom for the numerator and denominator of the statistical value $F\left(f_{1}=2\right.$ and $f_{2}=$ $=15$ ). Then from the statistical tables [5] the critical value of statistics was read $\mathrm{F}_{\mathrm{kr}}=\mathrm{F}_{(0.05 ; 2 ; 15)}=3.6823$ and the $\mathrm{F}_{\mathrm{obl}}$ value was determined, which was successively: $\mathrm{F}_{\text {obl }}\left(\mathrm{P}_{1}\right)=$ $=157.1 ; \mathrm{F}_{\mathrm{obl}}\left(\mathrm{P}_{2}\right)=119.4 ; \mathrm{F}_{\text {obl }}\left(\mathrm{P}_{3}\right)=357.1$. Since the condition $\mathrm{F}>\mathrm{F}_{\mathrm{kr}}$ is met in all three cases, the zero hypothesis must be rejected and it must be assumed in further diagnostic studies that, within the variability range under consideration, the active cross-sectional area of the $A_{\text {dol }}$ intake air channel has a significant effect on the specific enthalpy of the exhaust stream within one diesel engine cycle. 
Table 3. Values of the specific enthalpy of the exhaust gas stream $h_{\text {spalśr }}$ within one diesel engine cycle for the variable values of the active cross-sectional area of the $A_{\text {dol }}$ intake air channel, where: a) the result for the test at point $P_{1}=432 \mathrm{~W}$ of the control characteristic, b) the result for the test at point $\mathrm{P}_{2}=$ $768 \mathrm{~W}$ of the same characteristic, c) the result for the test at point $\mathrm{P}_{3}=1200 \mathrm{~W}$ of the above characteristic

a)

\begin{tabular}{|c|c|c|c|c|c|c|c|c|}
\hline \multirow{3}{*}{ Point } & \multicolumn{8}{|c|}{$\begin{array}{l}\text { Average value over one exhaust gas enthalpy cycle } h_{\text {śr }}[\mathrm{kJ} / \mathrm{kg}] \\
\text { for variable values of the active cross-sectional area of the intake air duct P1 (432 W; } 5.1 \mathrm{~A} ; \mathbf{7 2} \mathrm{V})\end{array}$} \\
\hline & \multirow{2}{*}{$\mathrm{A}_{\mathrm{dol}}\left[\mathrm{m}^{2}\right]$} & \multicolumn{7}{|c|}{ Number of experience } \\
\hline & & 1 & 2 & 3 & 4 & 5 & 6 & $\mathrm{y}_{\mathrm{i}}$ \\
\hline $\mathrm{A}_{\text {dol } 11}$ & $804 \times 10^{-6}$ & 12.1299 & 12.1986 & 12.2763 & 12.2176 & 12.2669 & 12.1493 & 12.2064 \\
\hline $\mathrm{A}_{\mathrm{dol} 12}$ & $603 \times 10^{-6}$ & 11.4980 & 11.3782 & 11.3742 & 11.3126 & 11.3567 & 11.5817 & 11.4169 \\
\hline $\mathrm{A}_{\text {dol } 13}$ & $401 \times 10^{-6}$ & 11.1331 & 11.4122 & 11.3092 & 11.3045 & 11.4661 & 11.3280 & 11.3255 \\
\hline
\end{tabular}

b)

\begin{tabular}{|c|c|c|c|c|c|c|c|c|}
\hline \multirow{3}{*}{ Point } & \multicolumn{8}{|c|}{$\begin{array}{l}\text { Average value over one exhaust gas enthalpy cycle } h_{\text {śr }}[\mathrm{kJ} / \mathrm{kg}] \\
\text { for variable values of the active cross-sectional area of the intake air duct P2 (768 W; } 6.8 \mathrm{~A} ; 96 \mathrm{~V} \text { ) }\end{array}$} \\
\hline & \multirow{2}{*}{$\mathrm{A}_{\mathrm{dol}}\left[\mathrm{m}^{2}\right]$} & \multicolumn{7}{|c|}{ Number of experience } \\
\hline & & 1 & 2 & 3 & 4 & 5 & 6 & yi \\
\hline $\mathrm{A}_{\text {dol } 21}$ & $804 \times 10^{-6}$ & 13.8992 & 13.6571 & 13.4404 & 13.3947 & 13.2752 & 13.1309 & 13.4663 \\
\hline $\mathrm{A}_{\text {dol 22 }}$ & $603 \times 10^{-6}$ & 12.2129 & 12.1734 & 11.9982 & 11.8355 & 11.9983 & 11.9656 & 12.0306 \\
\hline$A_{\text {dol } 23}$ & $401 \times 10^{-6}$ & 12.1310 & 12.2085 & 12.1043 & 12.1049 & 12.0821 & 12.0763 & 12.1179 \\
\hline
\end{tabular}

c)

\begin{tabular}{|c|c|c|c|c|c|c|c|c|}
\hline \multirow{3}{*}{ Point } & \multicolumn{8}{|c|}{$\begin{array}{l}\text { Average value over one exhaust gas enthalpy cycle } \mathrm{h}_{\mathrm{sr}}[\mathrm{kJ} / \mathrm{kg}] \\
\text { for variable values of the active cross-sectional area of the intake air duct P3 }(\mathbf{1 2 0 0} \mathbf{~ W} ; \mathbf{8 . 5} \mathbf{A} ; \mathbf{1 2 0} \mathbf{~ V})\end{array}$} \\
\hline & \multirow{2}{*}{$\mathrm{A}_{\mathrm{dol}}\left[\mathrm{m}^{2}\right]$} & \multicolumn{7}{|c|}{ Number of experience } \\
\hline & & 1 & 2 & 3 & 4 & 5 & 6 & $\mathrm{y}_{\mathrm{i}}$ \\
\hline $\mathrm{A}_{\mathrm{dol} 31}$ & $804 \times 10^{-6}$ & 15.4712 & 15.4883 & 15.3075 & 15.3299 & 15.0444 & 15.0994 & 15.2901 \\
\hline $\mathrm{A}_{\text {dol } 32}$ & $603 \times 10^{-6}$ & 13.0105 & 12.8378 & 12.9773 & 13.0444 & 12.9890 & 12.7919 & 12.9418 \\
\hline $\mathrm{A}_{\mathrm{dol} 33}$ & $401 \times 10^{-6}$ & 13.6214 & 13.6125 & 13.5034 & 13.2633 & 13.3270 & 13.2022 & 13.4216 \\
\hline
\end{tabular}

\section{Comments and final conclusions}

From the results of the calculation, it can be seen that the active cross-sectional area of the inlet air channel has a significant effect on the specific enthalpy of the exhaust stream within one diesel engine cycle. However, in order to consider the adopted method of assessing the significance of the influence of the input factors of the engine operation and its design structure on the output with the use of FisherSnedecor decomposition F statistics as fully useful for diagnostic tests, the experimental research programme should be extended. It is necessary, inter alia, to carry out further research to determine the effect (force) of changes in other input parameters (factors) on the defined diagnostic measures of the diesel engine exhaust gas temperature signal, which are the average peak-to-peak value, as well as the rate (intensity) of increase and decrease in its value for single cycles of operation for which no relevant statistical studies have yet been carried out.

In the next stage of diagnostic tests, it is also planned to draw up an energy balance in the engine with the use of Sankey jet diagrams, under the conditions of introduced changes in the values of selected structure parameters. This is to determine their energy effects, as an important fireimpact of the developed methodology for diagnosing compression-ignition engines, based on measurements and analysis of exhaust gas temperature.

\section{Bibliography}

[1] BALCERSKI, A. Siłownie okrętowe: podstawy termodynamiki, silniki i napędy główne, urządzenia pomocnicze, instalacje. Wydawnictwo Politechniki Gdańskiej. Gdańsk 1990.

[2] JAREMKIEWICZ, M. Odwrotne zagadnienia wymiany ciepła, występujące w pomiarach nieustalonej temperatury płynów. Rozprawa doktorska. Wydawnictwo Politechniki Krakowskiej. Kraków 2011.

[3] KORCZEWSKI, Z. Diagnostyka eksploatacyjna okrętowych silników spalinowych - tłokowych i turbinowych. Wybrane zagadnienia. Wydawnictwo Politechniki Gdańskiej. Gdańsk 2017.

[4] KORCZEWSKI, Z., PUZDROWSKA, P. Analytical method of determining dynamic properties of thermocouples used in measurements of quick - changing temperatures of exhaust gases in marine diesel engines. Combustion Engines. 2015, 162(3), 300-306.

[5] KORZYŃSKI, M. Metodyka eksperymentu. Planowanie, realizacja i statystyczne opracowanie wyników eksperymentów technologicznych. Wydawnictwo WNT. Warszawa 2017. 
[6] KUDREWICZ, J. Analiza funkcjonalna dla automatyków i elektroników. Państwowe Wydawnictwo Naukowe. Warszawa 1976.

[7] ŁUTOWICZ, M. Identyfikacja procesu sprężania okrętowego tłokowego silnika spalinowego dla potrzeb diagnostyki jego przestrzeni roboczych. Rozprawa doktorska. Akademia Marynarki Wojennej. Gdynia 2006.

[8] OLCZYK, A. Koncepcja pomiaru szybkozmiennej temperatury gazu z uwzględnieniem dynamicznej składowej temperatury. Pomiary Automatyka Kontrola. 2007, 53 Bis/9, 576579.

[9] PABIS, S. Metodologia i metody nauk empirycznych. Państwowe Wydawnictwo Naukowe. Warszawa 1985.

[10] PUZDROWSKA, P. Statystyka F rozkładu Fishera-Snedecora jako narzędzie do oceny istotności wpływu mocy silnika o ZS na wybrane miary diagnostyczne. Journal of Polish CIMAC. 2019, 14(1/18), 177-186.

[11] PUZDROWSKA, P. Metoda wyznaczania stałej czasowej termopary na podstawie pomiaru szybkozmiennej temperatury spalin wylotowych silnika o ZS. Zeszyty Naukowe Akademii Morskiej w Gdyni. 2018, 108, 115-133.

[12] PUZDROWSKA, P. Signal filtering method of the fastvarying diesel exhaust gas temperature. Combustion En- gines. 2018, 175(4), 48-52. https://doi.org/10.19206/CE2018-407

[13] PUZDROWSKA, P. Identification on damages in the inlet air duct of a diesel engine based on exhaust gas temperature measurements. Combustion Engines. 2019, 177(2), 108-112. https://doi.org/10.19206/CE-2019-219

[14] RUDNICKI, J., PUZDROWSKA, P., MARSZAŁKOWSKI, $\mathrm{K}$. Osłona termopary chłodzona wodą jako narzędzie zapobiegające zakłóceniom zewnętrznym podczas pomiarów temperatur szybkozmiennych spalin w kanale wylotowym silnika okrętowego. Journal of Polish CIMAC. 2017, 12(1), 97-104.

[15] SHANNON, C.E. A mathematical theory of cryptography. A classified memorandum for Bell Telephone Labs. USA 1945.

[16] WOJTATOWICZ, T.W. Metody analizy danych doświadczalnych. Wybrane zagadnienia. Wydawnictwo Politechniki Łódzkiej. Łódź 1998.

[17] ZACHAREWICZ, M. Metoda diagnozowania przestrzeni roboczych silnika okrętowego na podstawie parametrów gazodynamicznych w kanale zasilającym turbosprężarkę. Rozprawa doktorska. AMW. Gdynia 2009.
Patrycja Puzdrowska, MEng. - Faculty of Ocean Engineering and Ship Technology, Gdansk University of Technology.

e-mail: patpuzdr@pg.edu.pl 